\title{
EFFECTIVE MANAGEMENT OF ONLINE LEARNING DURING PANDEMIC AT SDN 1 TANAH TINGGI
}

\author{
Ina Magdalena ${ }^{1}$, Ayu Wahyuni ${ }^{2}$, Davina Dewi Hartana ${ }^{3}$ \\ ${ }^{1,2,3}$ Elementary Education Study Program, Universitas Muhammadiyah Tangerang, Tangerang, Indonesia
}

\begin{tabular}{|c|c|}
\hline Article Info & ABSTRACT \\
\hline Article history: & \multirow{6}{*}{$\begin{array}{l}\text { Effective learning can be defined as learning that succeeds in achieving the learning } \\
\text { objectives of students as expected by the teacher. But the Covid-19 epidemic has } \\
\text { disrupted the conventional learning process. So a solution is needed to answer these } \\
\text { problems. Online learning is an alternative that can solve this problem so this research } \\
\text { aim is to describe the effective management of online learning during a pandemic at } \\
\text { SD Negeri } 01 \text { Tanah Tinggi. This research is descriptive - qualitative research and data } \\
\text { collection techniques in this study are participant observation and in-depth interviews. } \\
\text { In order to achieve effective learning during pandemic, teachers are required to make } \\
\text { good and interesting learning designs. Five indicators of effective learning, namely } \\
\text { (1) management of the implementation of learning, (2) communicative processes, (3) } \\
\text { student responses, (4) learning activities, and (5) learning outcomes. Students can } \\
\text { understand and master IT, and students and teachers can communicate well through } \\
\text { Blended Learning. }\end{array}$} \\
\hline Received: 17-01-2021 & \\
\hline Revised: $14-03-2021$ & \\
\hline Published: $10-05-2021$ & \\
\hline Keywords: & \\
\hline $\begin{array}{l}\text { Online Learning } \\
\text { Effective } \\
\text { Covid-19 }\end{array}$ & \\
\hline
\end{tabular}

This is an open access article under the CC BY-SA license.

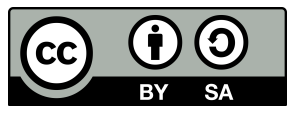

\section{Corresponding Author:}

Ina Magdalena,

Elementary Education Study Program, Universitas Muhammadiyah Tangerang,

Jl. Perintis Kemerdekaan I Babakan No.33, Kota Tangerang, Indonesia

Email: inapgsd@gmail.com

\section{INTRODUCTION}

Learning is the process of interaction between students, educators, and learning resources in a learning environment. Learning is an assistance provided by educators so that the process of acquiring knowledge can occur; mastery of skills and character; and the formation of attitudes and beliefs in students. In other words, learning is a process to help students learn well.

One of the notions of learning put forward by Gagne (1977) is that learning is a set of external events designed to support several internal learning processes. Furthermore, Gagne (1985) put forward his theory more fully by saying that learning is intended to produce learning, external situations must be designed in such a way as to activate, support, and maintain the internal processes contained in each learning event. Learning is an activity to change oneself, increase skills and knowledge (Kallesta, Yahya, \& Erfan, 2018).

Effective learning is learning that allows students to learn specific skills, knowledge, and attitudes that also make them happy. Effective learning encourages students to learn something useful, such as facts, skills, and value concepts and how to live in harmony with others or the desired learning outcomes. The needs and expectations of the community for good quality education services are the main trigger factors for innovation in educational management. School effectiveness and school-based quality improvement management is partly determined by the school's ability to communicate with the institutes above it.

According to Kyriacou (2009), effective learning includes two main points, namely active learning 
time and quality of instruction. The first thing relates to the amount of time spent by students during the lesson. That is how do students engage in the learning process to achieve the expected goals. The second has to do with the actual quality of learning itself. That is how the learning process or interaction can take place between teacher-students, students-students, and student-learning resources.

Miarso (2004) states that the effectiveness of learning is one of the quality standards of education and is often measured by the achievement of goals, or it can also be interpreted as the accuracy in managing a situation or "doing the right things". Hamalik (2001) states that effective learning is learning that provides opportunities by themselves or doing activities as widely as possible for students to learn. Provision of selfstudy opportunities and activities as widely as possible are expected to help students understand the concepts that are being studied.

Wotruba and Wright in Uno (2013) revealed that the results of their study in several studies revealed that seven learning indicators were said to be effective, namely: (1) good material organization, (2) effective communication, (3) mastery and enthusiasm for topics being taught, (4) positive attitudes towards students, (5) fair assessment, (6) flexibility in the learning approach, and (7) good student learning outcomes. Based on the seven indicators, the indicator of fair assessment and flexibility in the learning approach are classified as indicators that are difficult to measure. Meanwhile Reigeluth (1983) reveals, indicators of effective learning are: (1) accuracy of mastery, (2) speed for work, (3) level of learning transfer, and (4) level of retention. For accuracy of mastery, it can be focused on students and teachers. Students with good mastery after learning it means that the learning objectives have been achieved.

Online learning use learning applications or social networks. Online learning is learning that is carried out without doing face-to-face, but through existing platforms. All forms of learning materials, communication, and tests are also carried out and distributed online. This online learning system is assisted by several applications, such as Google Classroom, Google Meet, Edmodo and Zoom. Online learning certainly has its challenges. Students need not only a supportive atmosphere at home to study, but also an adequate internet connection. However, an effective learning process is equally important.

Blended learning is learning that combines or blends face-to-face learning and computer-based learning (online and offline) (Husamah, 2014). According to Thorne in Husamah (2014) reveals that blended learning is a combination of multimedia technology, CD Room, video streaming, virtual classes, voice-mail, e-mail, teleconferencing and online text animation. Blended learning has the following objectives, such as (1) helping students to develop better in the learning process according to their learning styles and learning preferences; (2) providing realistic, practical opportunities for teachers and students to learn independently, be useful, and continue to develop; (3) increasing flexibility scheduling for students by combining the best aspects of face-toface and online learning (Husamah, 2014). The components in blended learning are (1) Face to face Learning, (2) Offline E-learning, (3) Online E-learning, (4) Mobile Learning (M-learning).

\section{RESEARCH METHOD}

The type of research used is descriptive - qualitative. Data collection techniques in this study are participant observation and in-depth interviews. This type of research is used to describe the effective management of online learning during a pandemic at SD Negeri 01 Tanah Tinggi. Teachers at SD Negeri 01 Tanah Tinggi were key informants in this study.

\section{RESULT AND DISCUSSION}

Based on the results of research through observations about effective online learning management at SDN Tanah Tinggi 01, we get information from two opinions. From these two opinions, it is stated that there are five indicators of effective learning, namely (1) management of learning implementation, (2) communicative processes, (3) student responses, (4) learning activities, and (5) learning outcomes. Thus, learning is declared effective if all the indicators are in the minimum good category. If one of the indicators referred to is not yet classified as good (some have not reached 75\%), then it cannot be declared effective. Good lesson planning is certainly in accordance with the predetermined design. Therefore all teachers at SDN Tanah Tinggi 01 have planned good and effective learning for all their students. 


\subsection{Effective learning planning during a pandemic}

The homeroom teacher at SDN Tanah Tinggi 01 said that in order to create effective learning, good learning planning is needed, then how to create good learning plan is the problem. According to him, in order to create effective learning, the school creates an emergency covid curriculum and a teacher must prepare a good online lesson plan so that children can still get fun learning activities. The learning plan content is only 1 sheet, namely learning objectives, steps and assessments. Learning plan (in pandemic era) provides 1 material per day, so that children don't reluctant and are confused about understanding the material.

\subsection{An effective learning model to use when learning online}

The learning model currently used is Blended learning. Where there are offline meetings. Previously, the teacher formed groups of 4-6 students. This model is expected to optimize the development of students. Students can also do the experiment at home.

\subsection{Is this online learning effective for students?}

If asked whether it is effective or not, the answer is many of them are no. This is because there are lots of complaints from parents of students that they do not understand the material presented by the teacher, especially when 1th grade students. They have only been in school for a few months. They did not understand what school is, what was it like the school environment, suddenly there was the Covid 19 disaster, and the students were ordered to learn from home. The students might be happy because the school was closed and had to learn from home, but gradually it did not feel right because this has been going on for 1 year. The students are bored and lazy to learn. Therefore online learning like this is less effective.

\subsection{Difficulties experienced during online learning}

The difficulties experienced by parents and students is because the media is incomplete and quite limited (only smartphone). There are even parents who have financial difficulties so that parents do not have smartphone. Students end up not learning because they do not have smartphone. Students are happy if they learn directly, face to face, see interesting media directly. Learning that is done via video is less effective, because most children are lazy to watch the learning videos. The difficulties experienced by teachers are also very various, such as attitude assessment. Especially $1^{\text {st }}$ grade students have only been in school for a few months and haven't been met face to face with the teacher, so it is difficult for teachers to assess the characteristics of each child. Cognitive/knowledge assessment is difficult to do. If the teacher only judge from the results of the students' assignment, it is feared that it is not the child who does the task, but the parents. Therefore the teacher has difficulty assessing the child's cognitive skill.

\subsection{How is online learning effective?}

Education is the interaction between teachers and students is either direct or indirect. Due to limitations with cellphones, usually the teacher only sends messages via WhatsApp. There is less interaction between teachers and students, so in order to create effective online learning, the teacher wants to make groups consist of 6 students for each. For example, teacher make 5 groups for 32 students in 1th grade. The implementation is that each group learns face-to-face in different day. For example the 1st group will have face-to-face learning on Monday, and so on. This is held in order to make students listen with a focus on the explanation from the teacher directly and can interact with their peers, but still adhere to health protocols. It is held in one room and one day there are only 6 students. They keep their distance in class and use masks. Therefore, the teacher can assess each student directly.

\subsection{Advice on future online learning implementation}

The teacher have to be more creative in providing learning such as using attractive media, so that it can spur the enthusiasm for learning of the students.

\section{CONCLUSION}

Based on the results of the research and discussion carried out, it can be concluded that in order to achieve effective learning, teachers are required to make good and interesting learning designs. Five indicators of effective learning, namely (1) management of the implementation of learning, (2) communicative processes, (3) student responses, (4) learning activities, and (5) learning outcomes. 
In a situation like this, learning is certainly not effective. By using the concept of the Blended learning, educators hope that learning can be effective again even though it is not yet fully effective. Online learning can also use the concept of the ICT model, it is hoped that students can understand and master IT, and students and teachers can communicate well.

\section{REFERENCES}

Gagne, R. (1977). The Condition of Learning. New York: Holt, Renehart and Winston.

Gagne, R. (1985). The Condition of Learning Theory of Instrucion. New York: Holt, Renehart and Winston. Hamalik, O. (2001). Proses Belajar Mengajar. Jakarta: Bumi Aksara.

Husamah, H. (2014). Pembelajaran Bauran (blended learning). Jakarta: Prestasi Pustakara.

Kallesta, K. S., Yahya, F., \& Erfan, M. (2018). Analisis Faktor Penyebab Kesulitan Belajar IPA Fisika pada Materi Bunyi Kelas VIII SMP Negeri 1 Labuhan Badas Tahun Ajaran 2016/2017. Quark: Jurnal Inovasi Pembelajaran Fisika dan Teknologi, 1(1), 51-57. doi:10.31227/osf.io/dwh5e

Kyriacou, C. (2009). Effective teaching in schools. Theory and practice (3rd ed.) Cheltenham: Nelson Thornes Ltd.

Miarso, Y. H. (2004). Menyemai Benih Teknologi Pendidikan. Jakarta: Prenoda Media.

Reigeluth, Charles, M. (1983). Instructional Design Theories and Models: An Overview of Their Current Status. New Jersey: Lawrence Erlbaum Associates.

Uno, H. B. (2013). Teori Motivasi dan Pengukurannya. Jakarta: Bumi Aksara. 